\title{
A Review of Machine Translation Tools: The Translation's Ability
}

\author{
Tira Nur Fitria \\ Institut Teknologi Bisnis AAS Indonesia \\ tiranurfitria@gmail.com
}

\begin{abstract}
The objective of the research is to review the ability of online machine translator tools includes Google Translate (GT), Collin Translator (CT), Bing Translator (BT), Yandex Translator (YT), Systran Translate (ST), and IBM Translator (IT). This research applies descriptive qualitative. The documentation was used in this study. The result of the analysis shows that the translation results are different, both from the style of language and the choice of words used by each machine translation tool. Thus, directly or indirectly, whether consciously or not, each translation machine carries its characteristics. Machine translation technology cannot be separated from the active role of humans. In other words, it will always be the best choice for users to rely on expert translation rather than machine translation. But no machine translator can be as accurate as human skills in producing translation products. In particular, the field of translation is also concerned with machine translation to support the performance of translators in analyzing the diction used as an element of language. In this regard, it needs to be underlined that the existence of machine translation is an additional facility in the world of translation, not as the main means of translation because the sophistication of the machine will not be able to match the flexibility of the human brain's cognitive abilities in adjusting the translation results according to the existing context. Accurate translation is sometimes subjective, relatively often temporal. Therefore, it is permissible for translating by more than one machine translator.
\end{abstract}

Keywords: machine translation, translation tools, translation

\section{INTRODUCTION}

Translation between human languages has been a need in society for thousands of years (Trujillo, 2012 , p. 3). Translate is a transposition of a sourcelanguage text into target-language text (Poibeau, 2017). The translation is solving language divergence (Bhattacharyya, 2015). There may be differences in vocabulary and syntax between the two languages, making a translation impossible (Fitria, 2020a). Therefore, in general communication, translation plays a significant role (Rahutomo et al., 2019).

But, who can resist the sophistication presented by the technological era? The high demands on meeting human needs have led to the consideration of time efficiency as an essential aspect in achieving performance targets. No doubt that the use of automatic "assistant" machines is now widely relied on to make human work easier. Machine translation, often known as MT, is a subfield of computational linguistics that studies the use of software to translate text or voice from one natural language to another (Al-Tuwayrish, 2016). In a research and development field, machine translation (MT) is among the oldest among the various disciplines and applications of computer science to the study of natural language (Nirenburg et al., 2003). It is also supported by Lin \& Chien (2009) and Chéragui, (2012), machine translation (MT) is a sub-field of computational linguistics that is a contemporary technique of translation using computer aid.

As we have seen, machine translation is the use of machine translators to translate text from one language to another. Translation in this way has advantages, including the practicality of use, fast results, and the low cost required. We can compare it with human translator services, which are not necessarily available all the time, it also takes time to produce the translation result and also has high costs. Because it is not surprising that currently machine translation is used by many people and has become a necessity. It looks like machine translation is slowly shifting the human 
translator profession. It's no wonder professional translators are starting to worry about the existence of this powerful machine, which can produce translation results in seconds and also in multiple languages. Although the results of machine translation still have many shortcomings, technology tends to develop and become better.

On the internet, we can find anything we want to look for. For example, any information about lessons, all can be found easily on the internet. The presence of the internet can facilitate various human jobs. Coupled with the increasingly sophisticated technological devices, the internet is increasingly inseparable from the life of modern society today. The internet can also be very helpful for those of us who work as office workers or students. Processing texts or documents may become a daily routine for office workers or students. Sometimes there are texts or even documents that contain a foreign language and we do not understand the language. To make it easier to read, we can first translate the document into Indonesian. No need to use a dictionary, we can take advantage of document translator sites on the internet. Online translation tools for text or documents can also be referred to as translator sites on the internet. Of course, the presence of this free online translation site is very helpful for students or teachers who are working on translation assignments or projects. The reason is, we do not have to bother translating word for word from foreign languages. Especially if we need an online machine translator to replace it with the foreign language we need.

Several programs of translation are available for free download. Furthermore, this method is useful for saving time for translators since opening dictionaries take a long time (Fitria, 2018). Several sites provide special services to translate into another language that is understood, in this case, Indonesian. Apart from being quite practical, these sites allow us to use them for free. There are several choices of complete online translator sites, including. Here are some choices of online translator sites that we can choose from. There are now many online machine translators available with various languages and newer and more complete service features such as Google Translate, BingTranslator, Yandex Translator, and others.

Machine translation involves of Artificial Intelligence (AI) system (Wilks, 2008). Machine translation system automatically translates a text form or language to another language (Chan, 2018). The general machine translation is to learn how to translate from a large corpus of equivalent source and target sentences (Utiyama, 2009). This is typically a machine translation framework. We have an input (the source language), an output (the target language), and a model trying to produce the correct output. While Quah (2006) states that the initial goal of machine translation is to build a fully automatic high-quality machine translation that did not require any human intervention.

Research on the capabilities or comparisons of several machine translators may have not been widely carried out. Therefore, in this research, the researcher is interested to review and investigate the ability of several online machine translator tools includes Google Translate (GT), Collin Translator (CT), Bing Translator (BT), Yandex Translator (YT), and Systran Translate (ST).

\section{RESEARCH METHOD}

This research applies descriptive qualitative research. Hennink et al (2020) state that qualitative research is typically used for providing an indepth understanding of the research issues...". In other words, in descriptive research, researchers want to describe a certain phenomenon or trait, and not to find or explain the relationship between variables like in quantitative research. So that, the research wants to describe the ability of several online machine translation tools in translating texts.

The collection of documentation was compiled during a qualitative study (Given, 2008). Documentation in this study is used to complete research and to maximize research results. The example of document here is taken from an Indonesian article from (Fitria, 2020b) entitled "Penerapan Teknologi Informasi dalam Pembelajaran: Web-Based Learning dan Mobile- 
Based Learning di ITB AAS Indonesia Selama Masa Pandemi Covid-19".

There are several steps for analyzing data, they are data reduction, data display, and conclusion (Tashakkori et al., 2003). In this study, the researcher reduced the data. A large amount of data and the complexity of the data require data analysis through the reduction stage. The researcher presents narrative/description data into tables, matrices, graphs, networks, or charts. Furthermore, researchers conclude by looking at the results of data reduction. This is to find relationships, similarities, or differences to conclude response to the research objectives.

\section{FINDINGS AND DISCUSSION Findings}

The ability of several online machine translator tools includes Google Translate (GT), Collin Translator (CT), Bing Translator (BT), Yandex Translator (YT), Systran Translate (ST), and IBM Translator (IT) can be seen below:

Table 1. Translation in Abstract Section

\begin{tabular}{|c|c|}
\hline $\begin{array}{l}\text { Indor } \\
\text { Text }\end{array}$ & $\begin{array}{l}\text { Penelitian ini bertujuan untuk mengetahui jenis platform atau aplikasi e-learning } \\
\text { yang digunakan dalam pembelajaran baik Web-based Learning dan Mobile-based } \\
\text { Learning di ITB AAS Indonesia selama masa pandemi Covid-19. }\end{array}$ \\
\hline $\begin{array}{l}\text { Google } \\
\text { Translate (GT) }\end{array}$ & $\begin{array}{l}\text { This study aims to determine the type of e-learning platform or application used in } \\
\text { learning both Web-based Learning and Mobile-based Learning at ITB AAS Indonesia } \\
\text { during the Covid-19 pandemic. }\end{array}$ \\
\hline $\begin{array}{l}\text { Collin } \\
\text { Translator (CT) }\end{array}$ & $\begin{array}{l}\text { ais study aims to find out the types of e-learning platforms or applications used in } \\
\text { arning both Web-based Learning and Mobile-based Learning at ITB AAS Indonesia } \\
\text { aring the Covid-19 pandemic. }\end{array}$ \\
\hline BT) & $\begin{array}{l}\text { his study aims to find out the types of e-learning platforms or applications used in } \\
\text { arning both Web-based Learning and Mobile-based Learning at ITB AAS Indonesia } \\
\text { uring the Covid-19 pandemic. }\end{array}$ \\
\hline $\begin{array}{l}\text { Yandex } \\
\text { Translator (YT) }\end{array}$ & $\begin{array}{l}\text { This study aims to determine the type of platform or the e-learning application that } \\
\text { is used in learning Web-based Learning and Mobile-based Learning in ITB AAS } \\
\text { Indonesia during the period of the pandemic Covid-19. }\end{array}$ \\
\hline $\begin{array}{l}\text { Systran } \\
\text { Translate (ST) }\end{array}$ & $\begin{array}{l}\text { The study aims to know the type of platform or e-learning application used in } \\
\text { learning both Web-based Learning and Mobile-based Learning in ITB AAS Indonesia } \\
\text { during the Covid-19 pandemic. }\end{array}$ \\
\hline $\begin{array}{l}\text { IBM Translator } \\
\text { (IT) }\end{array}$ & $\begin{array}{l}\text { The research aims to know the type of platform or application of e-learning used in } \\
\text { the learning of both Web-based Learning and Mobile-based Learning at ITB AAS } \\
\text { Indonesia during the Covid-19 pandemic. }\end{array}$ \\
\hline
\end{tabular}

Based on table 1, shows the translation of texts in the abstract section (purposes of the study) by using several online machine translation tools.

English. In Google Translate (GT) and Yandex Translator (YT), the Indonesian word "mengetahui" is translated into "determine". In Collin Translator (CT) and Bing Translator (BT), the Indonesian word "mengetahui" is translated into "find out". While, in Systran Translate (ST)
There is similarity and difference in translating the Indonesian "mengetahui" into

and IBM Translator (IT), the Indonesian word "mengetahui" is translated into "know".

There is also similarity and difference in translating the Indonesian "jenis platform atau aplikasi e-learning" into English. In Google 
Translate (GT), the Indonesian phrase "jenis platform atau aplikasi e-learning" is translated into "type of e-learning platforms or applications". The words "platforms" and "applications" become plural forms. In Collin Translator (CT) and Bing Translator (BT), the

Indonesian phrase "jenis platform atau aplikasi e-learning" is translated into "types of elearning platforms or applications". All the noun words such as "types", "platforms" and "applications" become plural forms. In Yandex Translator (YT) and Systran Translate (ST), the Indonesian phrase "jenis platform atau aplikasi elearning" is translated into "type of e-learning platform or application". All the noun words such as "types", "platforms" and "applications" become singular forms. While, IBM Translator (IT), the Indonesian phrase "jenis platform atau aplikasi e-learning" is translated into "type of platform or application of e-learning" which shows plural form. But, this tool is different from YT and ST. In YT is written "the learning application", there is addition of article "the" followed by a noun phrase. In ST, is written "elearning application", there is addition of article "the" followed by a noun phrase. While in IT is written "application of e-learning". There is not followed by the definite or indefinite article "a" or "the", but using the preposition "of".

Table 2. Translation in Abstract Section

\begin{tabular}{lcl}
\hline Indonesian Text & $:$ & $\begin{array}{l}\text { Metode penelitian yang digunakan dalam penelitian ini adalah } \\
\text { penelitian gabungan kualitatif dan kuantitatif deskriptif. }\end{array}$ \\
\hline Google Translate (GT) & $:$ & $\begin{array}{l}\text { The research method used in this research is a combination of } \\
\text { qualitative and quantitative descriptive research. }\end{array}$ \\
\hline Collin Translator (CT) & $:$ & $\begin{array}{l}\text { The research method used in this study is qualitative and descriptive } \\
\text { quantitative combined research. }\end{array}$ \\
\hline Bing Translator (BT) & $:$ & $\begin{array}{l}\text { The research method used in this study is qualitative and descriptive } \\
\text { quantitative combined research. }\end{array}$ \\
\hline Yandex Translator (YT) & $:$ & $\begin{array}{l}\text { The research method used in this research is the research combined } \\
\text { qualitative and quantitative descriptive. }\end{array}$ \\
\hline Systran Translate (ST) & $:$ & $\begin{array}{l}\text { The research method used in this research was a qualitative and } \\
\text { descriptive quantitative joint study. }\end{array}$ \\
\hline IBM Translator (IT) & $\begin{array}{l}\text { The method of research used in this study is a combined qualitative and } \\
\text { quantitative research. }\end{array}$ \\
\hline
\end{tabular}

Based on table 2, shows the translation of texts in the abstract section (purposes of the study) by using several online machine translation tools. There is similarity and difference in translating the Indonesian "penelitian ini" into English. In Google Translate (GT), Yandex Translator (YT), and Systran Translate (ST), the Indonesian phrase "penelitian ini" is translated into "this research". While, in Collin Translator (CT), Bing Translator (BT), and IBM Translator (IT), the Indonesian phrase "penelitian ini" is translated into "this study".

There is similarity and difference in translating the Indonesian "gabungan" into English. In Google Translate (GT), the

Indonesian word "gabungan" is translated into "combination". In Collin Translator (CT), Bing Translator (BT), Yandex Translator (YT), and IBM Translator (IT), the Indonesian word "gabungan" is translated into "combined". While it is contrasted with Systran Translate (ST), the 
Indonesian word "gabungan" is translated into "joint". The example above also shows that Google Translate (GT), Collin Translator (CT), Bing Translator (BT), Yandex Translator (YT), and IBM
Translator (IT) use the linking verb in the nominal sentence "is" to show simple present form, while it contrasted with Systran Translate (ST) which use "was" to show simple past tense form.

Table 3. Translation in Abstract Section

\begin{tabular}{ll}
\hline Indonesian Text : & ari hasil analisis menunjukkan bahwa dosen tetap ITB AAS Indonesia \\
& enggunakan berbagai plartform atau aplikasi e-learning dalam proses belajar \\
& engajar selama masa pandemi Covid-19. Ada berbagai jenis platform e-learning \\
& ng digunakan yaitu berbentuk pembelajaran berbasis web atau Web-based \\
& arning dan pembelajaran berbasis seluler atau Mobile-based Learning. \\
& mbelajaran berbasis web yang digunakan adalah e-learning yang dikembangkan \\
& 2h institusi ITB AAS Indonesia dan dapat diakses melalui situs web. \\
\hline Google & om the analysis results show that the permanent lecturers of ITB AAS Indonesia \\
Translate (GT) & e various platforms or e-learning applications in the teaching and learning process \\
& Iring the Covid-pandemic 19. There are various types of e-learning platforms in \\
& e, namely in form Web-based learning or Web-based Learning and based learning \\
& obile or Mobile-based Learning. Web-based learning used is e-learning developed \\
& the ITB AAS Indonesia institution and can be accessed through the website. \\
\hline Ie results of the analysis show that permanent lecturers at ITB AAS Indonesia & ed various e-learning platforms or applications in the teaching and learning \\
Translator (CT) & ocess during the Covid-pandemic period. There are various types of e-learning \\
& atforms in use, namely in the form of web-based learning or web-based learning \\
& d mobile-based learning. Web-based learning used is e-learning developed by the \\
& B AAS Indonesia institution and can be accessed through the website.
\end{tabular}

Bing Translator

(BT) om the results of the analysis showed that ITB AAS Indonesia permanent sturers use various platform or e-learning applications in the teaching and arning process during the Covid-19 pandemic. There are various types of earning platforms used in the form of web-based learning or Web-based arning and mobile-based learning. Web-based learning used is e-learning veloped by ITB AAS Indonesia institution and can be accessed through the əbsite.

Yandex

Translator (YT)

om the results of the analysis showed that the lecturer ITB AAS Indonesia using variety of platform or the application of e-learning in the teaching-learning process Iring the pandemic of Covid-19. There are different types of e-learning platform ed is shaped web-based learning or Web-based Learning and learning-based sbile or Mobile-based Learning. Web-based learning used is an e-learning app veloped by the institution ITB AAS Indonesia and can be accessed through the sbsite .

Systran

Translate (ST) om analysis shows that current lecturers ITB AAS Indonesia uses various atforms or the e-learning application in the learning process during the Covid-19 ndemic. There are various types of e-learning platforms used in the form of websed learning or Web-based Learning and mobile-based learning or Mobile-based arning. Web-based learning that is used is e-learning, developed by ITB AAS donesia's institution, and accessible through the website. 
IBM Translator

(IT) om the results of the analysis showed that Indonesian lecturers of ITB AAS donesia used various plartform or e-learning applications in the learning process teaching during the Covid-19 pandemic. There are various types of e-learning atforms that are used in the form of web-based learning and Web-based learning $\mathrm{d}$ learning-based learning or mobile-based learning. The web-based learning used e-learning which is developed by the ITB AAS Indonesia institution and can be cessed via the website.
Based on table 3, shows the translation of texts in the abstract section (purposes of the study) by using several online machine translation tools. There is similarity and difference in translating the Indonesian phrase "dari hasil analisis menunjukkan" into English. In Google Translate (GT), the Indonesian phrase "dari hasil analisis menunjukkan" is translated into "From the analysis results show". The word "hasil" is translated into "results" become plural form then followed by the verb "show" which refers to an as singular form. In Collin Translator (CT), the Indonesian phrase "dari hasil analisis menunjukkan" is translated into "The results of the analysis show". The word "hasil" is same translated into "results" become plural form then followed by the verb "show" which refers to an as singular

form. The type of tenses in the verb "show" also refers to simple present tense. The translation from GT is almost the same as CT. In Bing Translator (BT), Yandex Translator (YT), and IBM Translator (IT), the Indonesian phrase "dari hasil analisis menunjukkan" is translated into "From the results of the analysis showed". The word "hasil" is same translated into "results" become plural form then followed by the verb "show" which refers to an as singular form. The type of tenses in the verb "show" also refers to simple past tense. While, in Systran Translate (ST), the Indonesian phrase "dari hasil analisis menunjukkan" is translated into "From analysis shows". The Indonesian word "hasil" is not translated into English. The word "analysis" is become singular form then followed by the verb "shows" which refers to an as singular form. The type of tenses in the verb "show" also refers to simple present tense.
There are also other similarities and differences in translating the Indonesian clause "dosen tetap ITB AAS Indonesia menggunakan" into English. In Google Translate (GT), the clause is translated into "the permanent lecturers of ITB AAS Indonesia use". Here, there is an addition of articles "the" and "of". The word "dosen" is translated into "lecturers" which refers to the plural form, then followed by the verb "use" as plural form by using the simple present tense. In Collin Translator (CT), the clause is translated into "permanent lecturers at ITB AAS Indonesia used". The word "dosen" is translated into "lecturers" which refers to the plural form, then followed by the verb "used" by using the simple past tense. Here, there is also the addition of the preposition clause "at ITB AAS Indonesia". In Bing Translator (BT), the clause is translated into "ITB AAS Indonesia permanent lecturers use". Here, there is not added by any preposition like in GT and CT. The word "dosen" is same translated into "lecturers" which refers to the plural form, then followed by the verb "use" as plural form by using the simple present tense. In Yandex Translator $(\mathrm{YT})$, the clause is translated differently into "the lecturer ITB AAS Indonesia using". The word "dosen" is translated into "lecturer" which refers to a singular form, then followed by the verb "using" by using the present participle 'V-ing'. In Systran Translate (ST), the clause is translated differently into "current lecturers ITB AAS Indonesia uses". The word "dosen" is still translated into "lecturers" which refers to the plural form, then followed by the verb "uses" as plural form by using the simple present tense. In this translation, as we can see, there is not found subject-verb agreement between subject and verb. The subject's "current lecturers" does not fit with 
the verb "uses". It should be followed by a verb in the plural form "use". In IBM Translator (IT), the clause "dosen tetap ITB AAS Indonesia" is translated into Indonesian lecturers of ITB AAS Indonesia". This tool does not translate the word "tetap" even add the word "Indonesian" into a double. But, "dosen" is translated into "lecturers" as plural form and translate the word "menggunakan" into "used" to refers to simple past form.

The example above also shows the similarities and differences in translating Indonesian words into English. First, in Indonesian word "menunjukkan" into English. In Google Translate (GT), Collin Translator (CT) and Systran Translate (ST) translate the word "menunjukkan" into "shows" which refers to simple present tense. While, in Bing Translator (BT) and Yandex Translator (YT), translate the word "menunjukkan" into "showed" which refers to simple past tense. Second, the Indonesian phrase "dosen tetap" into English. In Google Translate (GT), Collin Translator (CT), Bing Translator (BT) translate it into "permanent lecturers". These translation tools use "permanent" to translate "tetap". The word "dosen" is the same translated into plural form "lecturers". In Yandex Translator (YT), the phrase "dosen tetap" only translated into "lecturers" and removing to translate "tetap".
While, in Systran Translate (ST), these tools use "current" to translate "tetap" and not using the word "permanent" as i Indonesian word "menggunakan" into English. Both Google Translate (GT) and Bing Translator (BT) translated the word into "use" which refers to simple present tense. In Systran Translate (ST) translated the word into "uses" also which refers to simple present tense but different forms of the verb. Collin Translator (CT) and IMB Translator (IT) translate the word into "used" also which refers to simple past tense. While in Yandex Translator (YT) translated the word into "using" also refers to continuous or present participle.

There is similarity and difference in translating the Indonesian phrase "dapat diakses" into English. In Google Translate (GT), Collin Translator (CT), Bing Translator (BT), Yandex Translator (YT) and IMB Translator translate the phrase "dapat diakses" into "can be accessed". But, in Systran Translate (ST), this tool translates the phrase "dapat diakses" into the word "accessible". While in the translation of phrase "melalui". In Google Translate (GT), Collin Translator (CT), Bing Translator (BT), and Yandex Translator (YT) translate it into "through". While, it is contrasted with IMB Translator (IT) which translated "melalui" into via", not using "through". 
Table 4. Translation in Introduction Section

Indonesian Text : Pandemi Covid-19 telah merubah sistem di seluruh aspek kehidupan manusia, khususnya perubahan di bidang pendidikan. Pendidikan dari tingkat dasar hingga menengah saat ini dilaksanakan secara tatap muka kini harus dilakukan secara daring. Demikian juga pada tingkat pendidikan tinggi, pembelajaran harus dilaksanakan secara online. Semua berubah, sistem pembelajaran tatap muka diganti dengan sistem pembelajaran daring yang membatasi antara siswa dan guru, mahasiswa dan dosen. Sekarang ini, proses perkuliahan diarahkan untuk dilaksanakan tidak secara tatap muka untuk menghindari terjadinya perkumpulan manusia yang memungkinkan terjadinya penyebaran dan penularan virus Covid-19.

Google Translate: The Covid-19 pandemic has changed the system in all aspects of human life, in (GT) particular changes in education. The education system of the elementary to secondary level is currently carried out face-to-face, now it must be done online. Likewise at the higher education level, learning must be implemented online. Everything changes, the learning system face-to-face is replaced by an online learning system that limits between students and teachers, students and lecturers. Currently, the lecture process is directed to be carried out not face to face to avoid human gathering that allow the spread and transmission of the Covid-19 virus.

Collin Translator: The Covid-19 pandemic has changed the system in all aspects of human life, (CT) especially changes in education. Education from primary to secondary level is now conducted face-to-face now must be done online. Likewise, at the higher education level, learning must be conducted online. All changed, the face-toface learning system was replaced with an online learning system that restricted between students and teachers, students and lecturers. Currently, the lecture process is directed to be conducted not face-to-face to avoid the occurrence of human gatherings that allow the spread and transmission of the Covid-19 virus.

Bing Translator: The Covid-19 pandemic has changed the system in all aspects of human life, (BT) especially changes in education. Education from primary to secondary level is now conducted face-to-face now must be done online. Likewise, at the higher education level, learning must be conducted online. All changed, the face-toface learning system was replaced with an online learning system that restricted between students and teachers, students and lecturers. Currently, the lecture process is directed to be conducted not face-to-face to avoid the occurrence of human gatherings that allow the spread and transmission of the Covid-19 virus.

Yandex Translator: Pandemic Covid-19 has changed the system in all aspects of human life, in (YT) particular changes in the field of education. Education, from primary to secondary level current is implemented in a face-to-face must now be done online. Similarly, at the level of higher education, learning should be implemented online. All change, learning systems face-to-face replaced with a system of online learning that limit between students and teachers, students and lecturers. Today, the lecture is directed to be implemented not face-to-face to avoid the occurrence of human associations that allow the occurrence of the spread and transmission of the virus Covid-19.

Systran Translate: Pandemics Covid-19 have changed systems across all aspects of human life, (ST) especially changes in education. Education from elementary to middle level, 
when it is conducted in advance, must now be done online. Likewise at the higher education level, learning should be conducted online. All that changes, the face-to-face learning system is replaced by an online learning system that limits students and teachers, students and professors. Currently, the course process is aimed at not faceted to avoid human gathering that allow the spread and spread of Covid-19 virus.

IBM Translator (IT) : The Covid-19 pandemic has changed systems across all aspects of human life, especially changes in the field of education. Education from the primary to medium level currently is done in face-to-face is now required to be performed online. Likewise at higher education levels, learning must be carried out online. All changed, the face-to-face learning system was replaced by an online learning system that curtailed between students and teachers, students and lecturers. Today, the process of lecture is directed to take place not face-to-face to avoid the occurrence of human societies that allowed for the spread and transmission of the Covid-19 virus.

Based on table 4, shows the translation of texts in the abstract section (purposes of the study) by using several online machine translation tools. There is similarity and difference in translating the Indonesian phrase "telah merubah" into English. In Google Translate (GT), Collin Translator (CT), Bing Translator (BT), Yandex Translator (YT), and IBM Translator (IT) translate "telah merubah" into "has changed" or "has + V3" in the form of the simple present perfect tense. It fits with the subject agreement "Pandemic Covid-19" which refers to a singular form. While, in Systran Translate (ST), translate "telah merubah" into "have changed" or "have + $\mathrm{V}^{\prime \prime}$ in the form of the simple present perfect tense. It fits with the subject-agreement "Pandemics Covid-19" which refers to the plural form.

There is similarity and difference in translating the Indonesian word "khususnya" into English. In Google Translate (GT) and Systran Translate (ST) translate the word "khususnya" into "in particular". While, in Collin Translator (CT), Bing Translator (BT), Yandex Translator (YT), and IBM Translator (IT) translate the word "khususnya" into "especially".

There is similarity and difference in translating the Indonesian phrase "dilaksanakan" as passive form into English. In Google Translate (GT) translate the word "dilaksanakan" into "carried out". In Collin Translator (CT), Bing Translator (BT), and Systran Translate (ST) translate the word "dilaksanakan" into "conducted". In Yandex Translator (YT), translate the word "dilaksanakan" into "implemented". While, in IBM translator (IT), translate the word "dilaksanakan" into "done". It shows that all translation tools translated the word "dilaksanakan" into passive form into English.

There is similarity and difference in translating the Indonesian phrase "demikian juga" into English. In Google Translate (GT), Collin Translator (CT), Bing Translator (BT), Systran Translate (ST), and IBM Translator (IT) translate the word "demikian juga" into "likewise". But, Yandex Translator (YT) translates the word "demikian juga" into "similarly"

There is similarity and difference in translating the Indonesian phrase "semua berubah" into English. Google Translate (GT), translates the phrase "semua berubah" into "everything changes". Everything is always singular, so when used in a sentence it is always treated as a singular subject. In Collin Translator (CT), Bing Translator (BT), and IBM Translator (IT) translate the phrase "semua berubah" into "all changed". It tends to be in the form of the past. In Yandex Translator (YT) translate the phrase "semua berubah" into "all change". It tends to be in the form of present. While in Systran Translate (ST) translate the phrase "semua berubah" into "all that changed". There is an additional word of "that" after the word "all". The verb "changed" tends to be in the form of the past.

There is similarity and difference in translating the Indonesian phrase "tingkat dasar hingga menengah" into English. In Google 
Translate (GT), translate the phrase "tingkat dasar hingga menengah" into "elementary to secondary level". In Collin Translator (CT), Bing Translator (BT) and Yandex Translator (YT) translate the phrase "tingkat dasar hingga menengah" into "primary to secondary level". In Systran Translate (ST) translate the phrase "tingkat dasar hingga menengah" into primary into middle level". While, IBM Translator (IT) ) translate the phrase "tingkat dasar hingga menengah" into "primary into medium level".

There is similarity and difference in translating the Indonesian phrase "sekarang ini" into English. In Google Translate (GT), Collin Translator (CT), Bing Translator (BT), and Systran Translate (ST) translate the phrase "sekarang ini" into "currently". While, Yandex Translator (YT) translate the phrase "sekarang ini" different from Google Translate (GT), Collin Translator (CT), Bing Translator (BT), Yandex Translator (YT) and IBM Translator (IT) translate the word "sekarang ini" into "today".

There is similarity and difference in translating the Indonesian phrase "perkumpulan manusia" into English. Google Translate (GT) and Systran Translate (ST) translate the phrase "perkumpulan manusia" into "human gathering" which refers to a singular form. Collin Translator (CT) and Bing Translator (BT) translate the phrase "perkumpulan manusia" into "human gatherings" which refers to the plural form. In Yandex Translator (YT) translate the phrase "perkumpulan manusia" into "human associations" which refers to the plural form. These tools translate differently from GT, CT, BT, and ST which translate "perkumpulan" into the word "gathering". But, IBM Translator (IT) translates the phrase "perkumpulan manusia" into "human societies" which refers to the plural form.

\section{Discussion}

Machine translation tool is software that functions to replace humans in translating source language text into target-language text. Human intervention is not required during the translation process (it may be limited to a few clicks) because all processes are pre-programmed. In the direct translation approach, the computer program (MT Tool) recognizes the target language text, matches it with the entries in the dictionary then immediately generates the targetlanguage text. With the transfer approach, the MT program will analyze words, phrases, sentences, and paragraphs then identify their equivalents in its "database". After that, the target language text can be generated by the system.

There are several online machine translator tools analyzed in this research, they are Google Translate (GT), Collin Translator (CT), Bing Translator (BT), Yandex Translator (YT), Systran Translate (ST), and IBM Translator (IT). Every online machine translation tools have similarities and comparisons with other translation machines in translating.

First, Google Translate is provided by Google. Google developed a feee multilingual machine translation service known as Google Translator (Gunjan et al., 2019). This tool lets users enter what users want to say and it'll display the translated text to the other person. Not only that, but it also gives a dictionary-like approach to learning languages by giving you meanings of the terms, translation information, and example phrases or sentences. Google Translate can assist us if we have a large volume of text to translate or if we want to translate a whole web page. It also allows users to copy, share, listen to, and store the translated text, as well as produce simple translations sufficient enough for readers unfamiliar with other languages to grasp what they mean. When Google Translate creates a translation, it searches hundreds of millions of documents for patterns that will help it choose the best translation for users (Kerr, 2014). Second, Collin Dictionary Translator is not just findings word definitions and synonyms. But, it has an online translator tool that supports over 60 languages and allows users to type in a word, phrase, or sentence and have it translated for them. Because its translations are provided by Microsoft, users will not have access to as many features as users of the other standalone online translators on this list. It is still handy for fast translations, and the translated text has a simple copy button. Third, Bing Miscrosof Translator is provided by Microsoft. This translator is a cloud based multilingual translation service. It translates text from one language to another but also fro text to specch as well (Dorman et al., 2012). The translator identifies and instantly translates 
whatever text the users type into the input box especially if they do not know what language it is written in. The users may say the word, phrase, or sentence they want to translate and hear the translation aloud, copy, share, or use Bing to search the web if the microphone is turned on. Unlike Google Translate, which supports over 100 languages, Bing Microsoft Translator supports over 60 languages for up to 5,000 characters and adds a feature that allows you to provide some input on the translation. Fourth, Yandex Translate does not translate normal text translations, but it goes further to translate images and websites too for 99 languages, making it the best online translator for multiple uses. It is easy to use, works quickly, and can be used to learn new languages. The users can switch between languages while translating an image without re-uploading it if we upload it for translation. It also includes predictive typing, a dictionary with transcription, pronunciation, examples of how to use the word or phrase, and corrections for poor translations. Fifth, Systran Translate can translate brief documents of up to 3,000 characters. Any website or Web page may be translated into any language for free, with choices for fluid navigation, alternate meanings, presentation, and more. This tools receive Translate on-the-fly text and file translations by email. It is a web-based language translation service that is offered for free. To swiftly translate the information we want, we may rely on this online translation self-service option. Sixth, IBM Translator (IT) instantly translate papers, applications, and websites to reach new markets. This software converts documents from one language to another while maintaining the file's layout and type and all supported file formats. By default, neural machine translation is used for all language pairings. Deep learning is used in this innovative technology to increase translation speed and accuracy.

Every online machine translation tools have similarities and comparisons with other translation machines in translating. In translating of Indonesian word "mengetahui" into English, this word is translated differently into "determine", "find out" or "know". In translating of Indonesian phrase "penelitian ini" into English, this word is translated differently into "this research" and "this study". In translating the
Indonesian "gabungan" into English, this word is translated differently into "combination", "combined", and "joint". In translating the Indonesian phrase "jenis platform atau aplikasi elearning" into English, this phrase is translated differently into "type of e-learning platforms or applications" become plural form both in "types" and "platforms/applications", "types of elearning platforms or applications" all plural form, also type of e-learning platform or application" become singular form. In translating the Indonesian phrase "dari hasil analisis menunjukkan" into English. This clause is translated differently into "From the analysis results show", "The results of the analysis show", "From the results of the analysis showed" also "From analysis shows". The type of tenses in verb refers to different tenses of simple present tense and simple past tense. In translating the Indonesian phrase "dosen tetap ITB AAS Indonesia menggunakan" into English. This phrase is translated differently into "the permanent lecturers of ITB AAS Indonesia use", "permanent lecturers at ITB AAS Indonesia used", "ITB AAS Indonesia permanent lecturers use", "the lecturer ITB AAS Indonesia using", and into "current lecturers ITB AAS Indonesia uses". The type of tenses in verb refers to different tenses of simple present tense and simple past tense. In translation of Indonesian word "menunjukkan" into English. This word is translated differently into "shows", "showed" and "showing" which refers to verbs in the simple present tense, simple past tense, and continuous tense. In translating Indonesian phrase "dapat diakses". This word is translated differently into "can be accessed" and "accessible". In translating the word "melalui" into English, this word is translated into "through" and "via". In translating the Indonesian phrase "telah merubah" into English, this phrase is translated differently into "has changed" or "has + V3" also "have + V3" in the form of simple present perfect tense. In translating the Indonesian word "khususnya" into English, this word is translated into "in particular" and "especially". In translating the Indonesian phrase "dilaksanakan" as passive form into English. This word is translated differently into "conducted", "implemented" and "done". It shows that all translation tools 
translated the word "dilaksanakan" into passive form into English. In translating the Indonesian phrase "demikian juga" into English, this word is translated into "likewise" and "similarly". In translating the Indonesian phrase "semua berubah" into English, this phrase is translated differently into "everything changes", "all changed" and "all that changed". In translating the Indonesian phrase "tingkat dasar hingga menengah" into English, this phrase is translated differently into "elementary to secondary level", "primary to secondary level", "primary into middle level" and "primary into medium level". In translating the Indonesian phrase "sekarang ini" into English, this phrase is translated into "currently" and "today". The last, in translating the Indonesian phrase "perkumpulan manusia" into English, this phrase is translated differently into "human gathering", "human gatherings", "human associations" and "human societies".

In the law of translation, it is known as relative truth, which means that no translation is perfect. Truth in translation is sometimes subjective, relatively often temporal (Kardimin, 2018). Therefore, it is permissible for a text or document to be translated by more than one machine translator. Thus, the result can be predicted that the translation will be different, both from the style of language and the choice of words used by each machine translation. Variations of this translation are often known as variants or hues. Thus, directly or indirectly, whether consciously or not, each translating machine will carry its characteristics. These tools have the same goal of developing translation tools is to translate written materials across different languages (Kastberg \& Andersson, 2012).

Several reasons why machine translation technology cannot be separated from the active role of humans (Anugu \& Ramesh, 2020). In other words, it will always be the best choice for users to rely on expert translation rather than machine translation. With a variety of options, translation tools make the job of translating simpler (Daems et al., 2017). But, no machine translator can be as accurate as human skills. It is feasible to meet the translation demand using human translators (Rivera-Trigueros, 2021). Various factors make the role of translation important because machine translation is still not very accurate in producing translation products.

First, machine translation is just a passive memory that does not recognize the dynamics of culture. We know that each race has its language and style. More than that, each individual can even bring up various language trends. It is this linguistic trend creation that carries a contextual bias beyond the reach of machines. Machine translation is limited to an electronic dictionary containing millions of word entries, which are packed with certain syntactic codes. The performance will be maximized if the source language that is inputted is almost perfect according to the governance of the languages

contained in the machine entry. Moreover, we cannot deny the existence of various synonyms which may vary in the category of word entry. However, in the full sentence entry category, the translation machine is also unable to perform proper filtering of terms according to the required context and cannot make corrections.

Second, Machine translation has difficulty localizing language variations. New phrases continue to appear in the various existing dialects. The technological revolution has also contributed to the dissemination of this trend throughout the world. Machine translation will not be able to adapt to developments like these as humans do. The machine must always be updated regularly to "learn" new phrases according to the intensity of their occurrence. Programming finally has to be carried out continuously using various sophisticated algorithms for a significant period. Therefore, machine translation will always be several steps behind the achievements of human progress.

Third, machine translation is unable to replicate language style and language sentiment. Each text transcript has a different purpose of use and target audience. This will also affect the language style and language sentiment used. In connection with this point, legal documents will tend to present archaic diction in a very formal and rigid tone. Meanwhile, the opinion essay document will appear more flexible and light.

Fourth, the results of machine translation need to be re-examined. The user may be threatened with wasted time losing. The user also has the potential to do a re-translation of what the machine translator has produced. Issues 
related to grammar require an editing and manual reading process to obtain an equivalent meaning between the source language and the target language according to the context to be presented.

Fifth, in machine translation results, sometimes the confidentiality principle is lacking or not guaranteed. This is can be dangerous. Unpaid translation machines usually do not sign an NDA (Non-Disclosure Agreement), which is a kind of integrity pact related to the prohibition on disclosing user information. If we work with documents of a sensitive nature, such as medical documentation, financial reports, and employee and client information, we should always be vigilant when using machine translators. Due to the absence of NDA guarantees, machine translation is free to explore any data we input and list it as new entries for improved translation quality. This can happen to anyone at any time. The complexities of language development must get our special attention to increase our lingual sensitivity. Meanwhile, we must respond to the massive disruption of technology wisely. Machine translation technology is a reference facility for us, not a means to rely on to produce a final translation product. Therefore, it is best to consult a reliable translator for the translation of important documents.

In particular, the field of translation also deals with machine translation to support the performance of translators in analyzing diction used as a language element. In this regard, it should be underlined that the existence of machine translation is an additional facility in the world of translation, not as the main translation tool. Of course, because the sophistication of the machine will not be able to match the flexibility of the cognitive ability of the human brain in adjusting the translation results according to the existing context. It is not a taboo thing if we as users end up stuck in the middle of confusion when we try to translate a paragraph using machine translation. Even though the translation product has good performance and consistent efforts to update the translation product, of course, there are still shortcomings. Perhaps, the major difficulties that MT systems confront are correctly resolving the inherent ambiguity of language in the source text and sufficiently conveying its intended meaning in the target language or translation adequacy in a wellformed and fluent manner or translation fluency (Popel et al., 2020). Therefore, as a user, it is necessary to reconsider the use of machine translation like this if you want to dig up certain information that requires a translation process.

\section{CONCLUSION AND SUGGESTION}

\section{Conclusion}

In particular, the field of translation is also concerned with machine translation to support the performance of translators in analyzing the diction used as an element of language. In this regard, it needs to be underlined that the existence of machine translation is an additional facility in the world of translation, not as the main means of translation because the sophistication of the machine will not be able to match the flexibility of the human brain's cognitive abilities in adjusting the translation results according to the existing context.

It is not uncommon for translation users to end up stuck in the middle of confusion when we try to translate a paragraph using online machine translation tools, includes Google Translate (GT), Collin Translator (CT), Bing Translator (BT), Yandex Translator (YT) and Systran Translate (ST) and IBM Translator (IT). Even though the performance is capable and consistent updating efforts are being made. Therefore, we need to reconsider using machine translation like this if we want to dig up certain information that requires a translation process. With all the advantages and efforts of developers, several paid and free machine translators have their respective advantages or advantages, but we as users do not have to believe in the absolute truth of machine translation.

\section{Suggestion}

Although there are many tips on how to translate English that say that translation must be done by humans, it turns out that quite a lot of services still use the help of translation sites or applications. However, you also have to understand that the robot translator from the site will not be $100 \%$ accurate. Therefore, it's a good idea to do a combination of translations from the website and also manually. While the site does most of the translation, we must read and understand the resulting English translation. If 
we feel that some words are stuck, or their meaning does not match expectations or even the context, then use inference, generalize the meaning and also conclude the correct meaning. In this way, you can also learn about English and make proper translations.

\section{REFERENCES}

Al-Tuwayrish, R. K. (2016). An Evaluative Study of Machine Translation in the EFL Scenario of Saudi Arabia. Advances in Language and Literary Studies, 7(1), 5-10.

Anugu, A., \& Ramesh, G. (2020). A Survey on Hybrid Machine Translation. E3S Web of Conferences, $\quad 184, \quad 01061$. https://doi.org/10.1051/e3sconf/20201840106 1

Bhattacharyya, P. (2015). Machine Translation. CRC Press.

Chan, S. (2018). The Human Factor in Machine Translation. Routledge.

Chéragui, M. A. (2012). Theoretical Overview of Machine translation. Proceedings ICWIT. https://www.semanticscholar.org/paper/The oretical-Overview-of-Machine-translationCh\%C3\%A9ragui/aad01b2a642711ef0b4d7d 89d8d50fc268a222ce

Daems, J., Vandepitte, S., Hartsuiker, R. J., \& Macken, L. (2017). Identifying the Machine Translation Error Types with the Greatest Impact on Post-editing Effort. Frontiers in Psychology, https://doi.org/10.3389/fpsyg.2017.01282

Dorman, S. J., Wolf, K., Polyakov, N., \& Healy, J. (2012). Sams Teach Yourself Windows Phone 7 Application Development in 24 Hours. Sams Publishing.

Fitria, T. N. (2018). Translation Technique of English Abstract Translation in Journal Edunomika in 2018. English and Literature Journal, 5(2), 145-160. https://doi.org/10.24252/elite.v5i2a4

Fitria, T. N. (2020a). Translation Technique of English to Indonesian Subtitle in "Crazy Rich Asian" Movie. ELS Journal on Interdisciplinary Studies in Humanities, 3(1), 51-65. https://doi.org/10.34050/elsjish.v3i1.8415

Fitria, T. N. (2020b). Penerapan Teknologi Informasi dalam Pembelajaran: Web-Based Learning dan Mobile-Based Learning di ITB
AAS Indonesia Selama Masa Pandemi Covid-19. Prosiding Seminar Nasional \& Call for Paper STIE AAS, 487-496.

Given, L. M. (2008). The Sage Encyclopedia of Qualitative Research Methods. SAGE.

Gunjan, V. K., Diaz, V. G., Cardona, M., Solanki, V. K., \& Sunitha, K. V. N. (2019). ICICCT 2019 - System Reliability, Quality Control, Safety, Maintenance and Management: Applications to Electrical, Electronics and Computer Science and Engineering. Springer.

Hennink, M., Hutter, I., \& Bailey, A. (2020). Qualitative Research Methods. SAGE.

Kardimin, K. (2018). Ragam Penerjemahan. Mukaddimah: Jurnal Studi Islam, 2(1), 187-202. https://doi.org/10.14421/mjsi.21.1364

Kastberg, P., \& Andersson, T. B. (2012). Machine Translation Tools-Tools of the Translator's Trade. Communication \& Language at Work, 1(1), $34-45$. https://doi.org/10.7146/claw.v1i1.7238

Kerr, P. (2014). Translation and Own-language Activities. Cambridge University Press.

Lin, G. C., \& Chien, P. (2009). Machine Translation for Academic Purposes. Proceedings of the International Conference on TESOL and Translation. https://www.semanticscholar.org/paper/Ma chine-Translation-for-Academic-PurposesLin-

Chien/0939a3ed5b0eecc54e8a4c6dd5609bada c9ab935

Nirenburg, S., Somers, H. L., \& Wilks, Y. (2003). Readings in Machine Translation. MIT Press.

Poibeau, T. (2017). Machine Translation. MIT Press. Popel, M., Tomkova, M., Tomek, J., Kaiser, Ł., Uszkoreit, J., Bojar, O., \& Žabokrtský, Z. (2020). Transforming machine translation: A deep learning system reaches news translation quality comparable to human professionals. Nature Communications, 11(1), 1-15. https://doi.org/10.1038/s41467-02018073-9

Quah, C. K. (2006). Translation and Technology. Springer.

Rahutomo, F., Septarina, A. A., Sarosa, M., Setiawan, A., \& Huda, M. M. (2019). A review on Indonesian machine translation. Journal of Physics: Conference Series, 1402(7), 077040. https://doi.org/10.1088/17426596/1402/7/077040 
Rivera-Trigueros, I. (2021). Machine translation Trujillo, A. (2012). Translation Engines: Techniques systems and quality assessment: A for Machine Translation. Springer Science \& systematic review. Language Resources and Business Media.

Evaluation, 1-27. Utiyama, M. (2009). Learning Machine Translation. https://doi.org/10.1007/s10579-021-09537-5 MIT Press.

Tashakkori, A., Teddlie, C., \& Teddlie, C. B. Wilks, Y. (2008). Machine Translation: Its Scope and (2003). Handbook of Mixed Methods in Social \& Limits. Springer Science \& Business Media. Behavioral Research. SAGE. 